\section{Historie og erindring $\mathrm{i}$ dansk historiekultur}

\author{
Af Anette Warring
}

Fortællingen om besættelsestiden har været og er en kulturel nøglefortælling om efterkrigssamfundets centrale værdier og grundvilkår. Det giver derfor god mening at bruge den som reference $i$ en diskussion om historie og erindring i dansk historiekultur.

Men jeg vil nu alligevel starte et helt andet sted - med en historie, som I sikkert alle kender. Den handler om den tapre dragon Niels Kjeldsen fra krigen i 1864, der blev dræbt i forbindelse med en træfning ved Kolding under krigen. Fra 1880'erne blev han udpeget og benyttet som krigshelt i den nationalistiske og forsvarsbegejstrede offentlighed. Efter at være blevet dyrket som en falden dansk krigshelt i 20 år, især af højrefløjen, påviste forfatteren Karl Larsen i 1902 i en bog med anvendelse af kildekritisk metode, at Kjeldsen ikke var faldet i en heltemodig enekamp mod en preussisk overmagt, der oven i købet skulle have skudt ham bagfra, men at han var død under en i øvrigt helt legitim flugt netop som følge af overmagten. Billedet af dragon Kjeldsen måtte revideres eller rettere direkte tages ned, for brygger Jacobsen havde fået historiemaleren Frants Henningsen til at male et patriotisk maleri af ham, som nøje fulgte myten - „En helt fra 1864“ hed det - og det var hængt op på Frederiksborgmuseet. Ned kom Kjeldsen, og i dag hænger han sammen med sine preussiske såkaldte snigmordere hos Jyske Dragonregiment i Holstebro. Karl Larsens revision kunne ikke imødegås videnskabeligt, og Larsen blev i en lang afhandling bakket op af historie-

professor Kr. Erslev. ${ }^{1}$

Det blev beklaget dybt i den nationalt orienterede presse. Og her kommer vi til det, jeg vil bruge som afsæt for mit oplæg. I en kritik af videnskabens sandhedskrav skrev avisen Nationaltidende:

„Man berøver folket det ler, hvoraf det skaber billeder efter sin egen forestillingskreds, for at give det en sten, som der ikke er mere at gøre ved; man berøver det glæden ved at tænke sig, hvorledes helten kunne have båret sig ad, og man berøver det et virksomt middel til at forme forsætter om, hvorledes man selv vil handle under lignende forhold. Det første er ondsindet, og det andet er dumt. Professor Larsen har forgrebet sig på en legende, der var en glæde for den kreds, hvor den levede ... det er denne onde og ukloge handling, som har vakt røret. Han har gjort attentat på noget af det lidet, som folket med rette kalder for sin ejendom, som det værner om som helligt gods, som det åndeligt lever af, og som hverken han eller prof. Erslev kan erstatte".

Selvom sproget er af en anden tid og det historiske stof et andet, så var synspunktet det samme i en leder knapt 100 år efter i avisen Politiken i anledning af Claus Brylds og min bog Besattelsesti- 
den som kollektiv erindring. ${ }^{3}$ Synspunktet var, at det selvfølgelig er vigtigt at påvise egentlige løgne eller ekstreme mangler i fortællinger om fortiden, men at den mytologiske fortælling, „der gør nazismen til civilisationssammenbrud og modstandsbevægelsen til en moralsk reference“, er „en meningsfuld forenkling af et stykke ægte, erfaret historie, og den bør derfor ikke dekonstrueres", skrev avisen. ${ }^{4}$ Politiken er bestemt ikke ene om at mene, at mytiske fortællinger om fortiden er nødvendige og ønskelige, blot de hører til de gode af slagsen, sådan som besættelsesmytologien gør med sit gode politiske og etiske budskab om forsvar for nation, demokrati og menneskerettigheder. En HF-klasse jeg diskuterede med for nylig argumenterede ihærdigt for det samme, og faktisk er der historikere og antropologer, der mener, at historie kun kan spille en aktuel og identitetspolitisk rolle, hvis den antager mytens form, hvis historie gøres til erindring, så at sige. Det er et synspunkt, som altså omvendt hviler på den antagelse, at historiefaglig kritik og flertydighed er uforenelig med historisk identitet eller sagt på en anden måde, at historisering virker identitetsopløsende. Andre igen mener, at historikerne skal holde sig langt væk fra identitetspolitik, at det er noget der hører til præsternes, politikernes og kunstnernes gebet. Disse forskellige positioner kan findes blandt historikere, der interesserer sig for historiekulturelle, erindringshistoriske og kulturarvsmæssige problemstillinger. ${ }^{5}$

Hvad der tematiseres her, er den klassiske diskussion om historiens og historikernes samfundsmæssige rolle som henholdsvis myteafslører og/eller normdanner. Og på et mere grundlæggende plan handler det om forholdet mellem Mythos og Logos, mellem historievidenskabens krav om objektivitet, logisk og rationel argumentation, og så erindringens subjektivitet, følelsesmæssige bindinger og værdimæssige formidling. Og det handler om forholdet mellem historisering og relativering på den ene side og på stillingtagen og værdistandpunkter på den anden.

Jeg vil diskutere disse problemstillinger gennem to temaer:

1) For det første forholdet mellem historie og erindring. Her vil diskussionspunktet være: kan og bør historie og erindring adskilles eller bør de bringes nærmere hinanden?

2) For det andet historiens og historikerens identitetspolitiske rolle: Her vil diskussionspunktet ikke være, om den bør spille en sådan, for det er både uundgåeligt og ønskeligt, men derimod om hvilken form for fortidsforvaltning, der skaber betingelser for en demokratisk historiekultur.

For det første historie og erindring. Det er vigtigt, at historikerne besinder sig på, at den historiefaglige virksomhed kun er en del af samfundets samlede historieproduktion, og at historiebevidsthed skabes af andre end historikere og af andet end vores undervisning og bøger. Det har ikke været noget problem at konstatere, hvad angår besættelsestidens historie. For siden omkring 1970 har besættelsesforskningen og erindringen - her forstået som kulturel, offentlig artikuleret erindring 
eller med et andet udtryk som kollektiv erindring - taget hver deres ud-viklingsvej og fjernet sig mere og mere fra hinanden. Mens forskningen nuancerede den entydigt sort-hvide konsensusfortælling, ja faktisk nærmest blev helt underlagt et konfliktorienteret paradigme, så blev erindringen om besættelsestiden mere og mere stivnet, rituel og mytologiseret. Historieforskningen spillede en helt marginal rolle og satte ikke afgørende spor i den kollektive erindring. Der har været, hvad man kan kalde et nærmest totalt kommunikationssammenbrud mellem historie og erindring og på det konkrete plan mellem historikere og modstandsveteraner.

Konflikterne har udspillet sig som en række erindringspolitiske kampe, som jeg ikke skal komme nærmere ind på her, men blot fremhæve et fælles mønster. Umiddelbart skulle man jo tro, at det man sloges om i efterkrigstiden også var det, der var den vigtigste konflikt under besættelsen: skulle man samarbejde med den tyske besættelsesmagt eller skulle man yde modstand. Men det var det ikke. Konflikterne opstod især og blev særligt voldsomme, når det var modstandsbevægelsens betydning eller modstandskampens meningsfuldhed, der direkte eller indirekte blevet anfægtet. Eller de opstod når modstandsbevægelsen blev sat i kritisk belysning ved at man påviste manglende effektivitet i dens militære kamp, fejl i likvideringer af formodede stikkere, ved at man kritiserede retsopgøret el.lign. Det var ikke den historiske konflikt mellem samarbejdspolitikken og modstandslinjen, der satte dagsordenen for de store offentlige historiepolitiske kampe, når vi ser bort fra de første par år efter krigen.

Det var som regel primært modstandsbevægelsens veteranmiljøer, der i udgangspunktet protesterede og almindeligvis var veteranmiljøernes højre- og venstrefløj forenet i protesterne. Man kan tale om, at de udgjorde et erindringsfællesskab, der på tværs af dagsaktuelle politiske uenigheder forfulgte samme synspunkter, når det gjaldt fortolkninger af besættelsestidens historie, især når de mente at denne på den ene eller anden måde relativerede deres indsats og de værdier, som de stod for. Protesterne hentede derefter typisk mere eller mindre støtte i offentligheden og havde oftest stor gennemslagskraft, så stor, at forestillinger og udsendelser blev taget af plakaten og tv-udsendelser flyttet, dementier og undskyldninger leveret. $^{6}$

Forskningsresultater blev imidlertid ikke revideret, så vidt jeg ved. Historikerne blev måske ind imellem nok så forskrækkede over reaktionerne, men mente ikke protesterne anfægtede deres forskning. De udgjorde et historiepolitisk fællesskab bundet sammen af den fælles profession. Det var som befandt veteraner og historikere sig i hver deres verden. Eller måske mere præcist sagt: når dialogen ikke kom i stand, skyldtes det, at de to parter opererede med hvert deres sandhedsbegreb. Fortællingernes gyldighed blev nemlig begrundet på forskellig måde.

Modstandsveteraner og andre med selvoplevet erindring fra besættelsestiden fremførte gang på gang, at de 
ikke kunne genkende historikernes fremstilling, og at den historiske fortolkning virkede sårende og ærekrænkende. Og gang på gang blev det fremført af deres talerør i medier og Folketing, at historikere, kunstnere og journalister, der ikke selv havde oplevet besættelsestiden ikke havde forudsætning for at forstå og formidle dens historie. Som en mere eller mindre selvbestaltet repræsentant for modstandsbevægelsen hævdede den nu afdøde Frode Jakobsen gang på gang, at historikerne havde så stor afstand til besættelsestiden, at de ikke var i stand til at trænge ind dens væsen. Historikerne blev kritiseret for manglende indføling, empati og sympati, og for at forlade sig for meget på de skrevne kilder, på dokumenterne, for som aktørerne fremførte, så betød modstandskampens vilkår, at det vigtigste aldrig blev skrevet ned. Det var synspunkter båret af den forståelse, at den selvoplevede erindring ikke alene giver den sande indsigt men også en særlig ret til at bestemme, hvad der skal erindres, og hvad der skal glemmes.

Her overfor stod historikerne og hævdede deres fortolkningsret med henvisning til deres videnskabelige metode og rationelle argumentation. De bidrog til kløften og den manglende dialog ved at fremhæve distancen og det lidenskabsløse, analytiske blik som det største aktiv for en god analyse af besættelsestidens historie, og identifikationen, empatien som den absolut største fare. Et par eksempler: Ved Henrik Stevnsborgs disputatsforsvar fremførte opponenten Ditlev Tamm netop, at det var fortjenstfuldt, at Stevnsborg havde været i stand til at gennemføre, hvad han kaldte en lidenskabsløs analyse af politiets rolle, hvilket han tilskrev Stevnsborgs generationstilhørsforhold. Også Aage Trommer har ofte prist „distancen til stoffet, viljen og evnen til at træde et par skridt tilbage og se det udefra“, som helt afgørende for en god historisk analyse - senest i sin forskningsoversigt i forbindelse med 50 -året for befrielsen. ${ }^{8}$ Identifikationen ses som den absolut største fare - den kritiske distance som det største aktiv for en god analyse.

Et arketypisk eksempel på, at den dybe afgrund mellem historie og erindring skyldes to vidt forskellige meningsgivende referencer, var Trommers afhandling om jernbane-sabotagens minimale betydning for den militære krigsudvikling. Trommer holdt sig på sin side strengt og afgrænset til netop dette militærhistoriske undersøgelsesfelt, mens modstandsveteranerne på deres side fastholdt, at jernbanesabotagens betydning også måtte vurderes i et politisk perspektiv og i forhold til den indsats og de ofre, sabotagen havde krævet. De stærke reaktioner på, hvad de opfattede som en nedvurdering af modstandsbevægelsens betydning, kulminerede i en leder i dagbladet Information skrevet af tidligere modstandsmand og senere chefredaktør Børge Outze, der fremførte, at der i anledning af doktorafhandlingens forsvar ville blive nedlagt blomster på jernbanesabotørers grave rundt om i landet. ${ }^{9}$ Hvordan diskutere eller imødegå et sådan såkaldt argument? Men på den anden side må det anerkendes som et problem for histori- 
kere, hvis folk overhovedet ikke kan genkende historikerens billede af besættelsestiden i relation til egne eller kulturelt overleverede erindringer.

Denne afstand mellem historie og erindring samt det faktum, at den offentlige scene har været besat og domineret af den hegemoniske grundfortælling, ikke af den faghistoriske fortælling, kunne give anledning til at drage to konklusioner, som jeg imidlertid mener er forkerte. For det første den, at historie og erindring hverken har, kan eller bør have noget med hinanden at gøre. For det andet, at der ikke i denne sammenhæng hersker noget demokratiproblem, i den forstand, at det almindeligt herskende hierarki mellem fagfolk og lægfolk, imellem historievidenskab og personlig erindring, synes at være vendt på hovedet, når det gælder den kollektive erindring om besættelsestiden.

Til det sidste er at sige, at når erindringens fortolkningsprivilegium i vid udstrækning er slået igennem, skyldes det ikke et særligt demokratisk historiekulturelt islæt, men derimod det forhold, at den fortælling modstandsveteraner og senere politikere og massemedier repræsenterede og var bærere af, var nødvendig for konstruktionen af den national-patriotriske fortælling om Danmark som en modstandsnation. Hele nationen har siden 1945 skulle knyttes til modstandsbevægelsen og fortiden har skulle anskues ud fra den synsvinkel, som under besættelsen var modstandsbevægelsens. Der er sket det, man kunne kalde en nationalisering af modstanden. At der er modstandsveteraner, der føler sig ubekvemme ved den kollektive erindrings besættelsesfortælling, er dog også vigtigt at huske på. Denne fortælling levner nemlig ikke plads til de ofte modstridende og am-bivalente erindringer, der også hersker hos dem.

Samtidig er det vigtigt at understrege, at når det hævdes, at den bedste og mest sande historie skrives med udgangspunkt i den selvoplevede erindring, så er det et selektivt argument, da det kun gælder den erindring, som ifølge kollektivtraditionen er båret af personer, der stod på den rigtige side. Det er ikke al selvoplevet erindring fra besættelsestiden, der har denne magtfulde status. Der er stemmer, som ekskluderes, der er nogle, der fortælles ud af det nationale fællesskab, nemlig den erindring, der er båret af dem, der stod på den forkerte side, eller af dem, der er vokset op med forældre eller slægtninge til disse mennesker. Her fungerer det helt omvendt. I stedet for at blive opfattet som specielt autentisk, som noget man i særlig grad bør lytte til, hvis man vil forstå, hvordan det virkelig var under besættelsen, så opfattes det som suspekt, som et forsøg på at legitimere, undskylde eller i værste fald forsvare, når erindring og erfaringer fra den forkerte side bringes frem $\mathrm{i}$ offentligheden.

Men hvordan skal man nærmere forstå denne - i denne sammenhæng - massive diskrepans mellem historie og erindring, og hvilken konsekvens skal man drage? Blandt de fleste erindringshistorikere er der efterhånden enighed om, at selvom der er afgørende forskelle og modsætninger mellem historiens og erindringens indhold, rationaler og især funktioner, så er de 
samtidig umuligt at skille helt ad. Historieforskningen er f.eks. ikke uberørt af erindringen eller af samtiden. Og omvendt er erindring en kompleks sammenvævning af biografi, selvoplevelse og historieformidling. Den franske erindringshistoriker Pierre Nora har brugt den meget rammende metafor, at erindring er som træet, mens historie er som barken. ${ }^{10}$ Hermed markerer han på én og samme tid adskillelsen og den organiske forbindelse mellem erindring og historie. Historikernes opgave kan følgelig være to: den kan være som knivens adskillende snit mellem træ og bark, som Nora sammen med David Lowenthal og Eric Hobsbawm foretrækker. ${ }^{11}$ Altså en position, hvor det handler om til stadighed at gøre klart og rendyrke, hvad der er forskellen mellem historie og erindring, hvad der er såkaldt historisk korrekt, og hvad der er erindring. Eller den kan tage udgangspunkt i den nok adskilte men dog organiske forbindelse, eller gråzone, mellem historie og erindring, mellem intellekt og følelse, og som vil kunne danne udgangspunkt for en relativering af faghistorien og en stræben efter dialog mellem historie og erindring, mellem historikere og lægfolk, sådan som Raphael Samuel og herhjemme Bernard Eric Jensen har talt for. ${ }^{12}$

At det sidste er ønskeligt, er jeg ikke i tvivl om, og jeg mener, at historikerne kunne have spillet andet end en marginal erindringspolitisk rolle, hvad angår den kollektive erindring om besættelsestiden, hvis de i højere grad havde set forholdet mellem historie og erindring som et kontinuum og ikke som et absolut skel. Indlevelse i de historiske aktørers værdigrundlag er nødvendig for at forstå deres intentioner og handlingsvalg. Så jeg længes ikke efter den - snarlige - situation, hvor den selvoplevede erindring ikke længere kan bringes ind i den erindringspolitiske kamp om besættelsestiden af dens aktører. Og jeg er altså ikke enig, når ellers udmærkede mennesker som Hobsbawm og Habermas og andre med dem entydigt afviser identifikationen som en blindgyde og alene hylder en omgang med fortiden, der hviler på distancering og retrospektivitet, og mener at historikernes politiske rolle må begrænse sig til at svinge den føromtalte kniv. ${ }^{13} \mathrm{Om}$ vendt mener jeg dog heller ikke, at historikerne skal opgive den kritiske historisering af fortidige begivenheder, eller at en sådan historisering skulle være uforenelig med en normdannende og identitetspolitisk rolle. Historie kan have en identitetsdannende funktion uden at den så at sige forvandler sig til erindring og overtager dens mytiske form, således som jeg indledningsvis referede Politiken-lederen for at mene.

Lad mig uddybe. At den kollektive erindring eller Den store myte, som Hans Kirchhoff kalder den, om fællesskabet og den fælles nationale kamp under besættelsen har haft en afgørende integrerende og samlende effekt på den nationale identitetsdannelse, kan der ikke herske tvivl om. ${ }^{14}$ Selvom besættelsestiden er blevet aktualiseret til vidt forskellige politiske formål, f.eks. både for og imod EU og både for $o g$ imod NATO, så har besættelsestiden hovedsageligt fungeret som reference- 
punkt for grundforestillinger i den politiske kultur om demokrati og folkefællesskab, om frihed knyttet til vestlig integration og vestligt militært samarbejde. Efter Murens fald, hvor det antikommunistiske projekt forsvandt, blev besættelsestiden mest brugt som argumentation for en mere aktivistisk dansk udenrigspolitik og for et forsvar for menneskerettigheder i almindelighed. På trods af, at den politiske brug af besættelsestiden ind imellem har været særdeles håndfast og har taget form af en endog meget udtalt instrumentalisering af fortiden til politiske formål, så er det ikke historiens identitetspolitiske rolle $\mathrm{i}$ sig selv, jeg anfægter. Fortid og nutid er dialektisk forbundne, og jeg synes derfor også, at det er relevant, når journalister stiller historikerne spørgsmålet: Hvad kan vi lære af det og det, hvad kan vi bruge det til i nutiden og i fremtiden. Det bør en historiker kunne svare på, og ikke kun holde sig til at fremlægge sin version af historien eller påpege eventuelle fejl i andres.

Det er imidlertid afgørende på hvilken måde, fortiden aktualiseres. Her tjener den kollektive erindring og den politiske aktualisering af besættelsestiden som et illustrativt eksempel. For som jeg sagde tidligere, så har fagvidenskaben og erindringen taget hver sin udviklingsvej i de sidste 30 år. Mens faghistorien nuancerede fortællingen, blev den kollektive erindrings fortælling ritualiseret og mytologiseret. Den kollektive erindring om besættelsestiden blev mere og mere reduceret til en abstrakt fortælling, der kunne levere figurer, temaer og stemninger til en politisk strid, der handlede om noget helt andet, f.eks. utilfredshed med den siddende kulturminister, utilfredshed med forsvars- eller udenrigspolitikken eller noget helt tredje. Ser man på udviklingen i 1990'erne, så blev den offentligt iscenesatte besættelsesfortællings elementer reduceret, således at kun to historiske aktører kom til at stå tilbage på scenen: En lille ubestemt gruppe af kollaboratører og nazister, der samarbejdede med tyskerne, og som det ikke var værd at spilde mange ord på, og så modstandsbevægelsen, der satte sig til modværge mod besættelsesmagten og dermed reddede Danmarks frihed og ære. Samarbejdspolitikken og den store del af befolkningen, der forholdt sig passive, var stort set forsvundet fra den historiske scene, og i særlig grad de interesser, ræsonnementer og værdier, der var dens grundlag. I det omfang samarbejdspolitikken overhovedet blev nævnt, blev den fordømt på et moralsk grundlag uden forsøg på at udlægge, hvilke grunde der var til, at en sådan politik kunne se meningsfuld ud i krigens første år. ${ }^{15}$ Den historiske fylde var altså væk. Hermed blev sammenknytning af besættelseshistorien og universelle værdier som menneskerettigheder, demokrati og ytringsfrihed til en absolut fortælling om absolutte værdier, der hverken skulle diskuteres eller forstås i deres specifikke historiske kontekst. De blev besunget og konstateret, ikke analyseret og begrundet. ${ }^{16}$ Dermed blev der i egentlig forstand tale om historieprojicering, dvs. projicering tilbage i fortiden af ønsker om, hvordan man gerne vil optræde og præsentere sig i nutiden. 
Og hvad er der så galt i det? Er det ikke positivt, at en sådan fortælling kan opbygge identitet f.eks. hos de unge, som jo netop har været en særlig målgruppe for statsligt iscenesatte jubilæer, statsligt finansieret oplysningsarbejde og i det hele taget historieformidlingen om besættelsestiden? En identitet, hvor værdier som demokrati, frihed og menneskerettigheder værdsættes og giver et handlingsberedskab til at forsvare disse værdier mod anslag fra nazisme og anden totalitarisme? Jeg mener imidlertid, at en mytologiseret brug af fortiden er det modsatte af en demokratisk historiekultur, uanset at det netop er den værdi, der formidles. Den mytologiske fortællings styrke er, at den åbner for indlevelse og identifikation, der gør den levedygtig og følelsesmæssig forankret. Problemet er dens lukkede, selektive og absolutte karakter, der rejser et effektivt værn mod refleksion og kritik. Enhver kritik eller blot spørgende diskussion af den mytiske fortællings proportioner, budskab eller mening kommer nemlig til at fremstå som en kritik af de absolutte værdier, som der i dette tilfælde oven i købet var nogen, der gav deres liv for. Døden, ikke mindst offerdøden, er jo et stærkt budskab og svært at hamle op med i en meningskamp om samfundets kulturelle erindring.

Hvad angår den mytiske fortællings formodede handlingsgivende funktion, så er det min pointe, at det abstrakte og naturliggjorte moralske budskab i den mytiske besættelsesfortælling næppe er meget værd som retningsgiver i nutiden, eller som vaccine mod totalitære tendenser, sådan som forsvarerne af den gode myte hævder. ${ }^{17}$ Både positiv mytologisering af modstanden og negativ mytologisering af nazismen er det modsatte af Vergangenheitbewältigung - aktiv fortidsbearbejdning. Hermed gøres både de positive og negative værdier til natur, ikke politik. Over for mytologiseringen vil jeg stille historiseringen, der erkender, ja oven i købet fremhæver besættelsestiden som en tid, hvor værdistandpunkter og handlingsvalg langt fra var entydige, men derimod komplicerede og vanskelige. En sådan kritisk og selvstændig forholden sig til fortidens begivenheder vil ruste langt bedre til reflekterede aktuelle handlingsvalg, som er det, der i sidste ende kan sikre demokratiet.

Det er klart, at der med historiseringen altid vil følge en vis værdirelativering, og at den kan føre for vidt, i den forstand, at den afskærer forbindelsen mellem fortid og nutid og så at sige trækker sig tilbage og nægter at blande sig i og forbinde sig med samtidens aktuelle udfordringer. Det er ligeledes klart, at historisering ud fra bestemte interesser kan misbruges. Det sker f.eks. aktuelt i Chile, hvor militæret netop bruger den kontekstualisering og historisering af militærets rolle i kuppet i 1973 og i de efterfølgende krænkelser af menneskerettighederne, som historikerne foretog i Rettigkommissionens rapport til at frikende militæret for ansvar. Men at det ikke altid behøver at være sådan, viser det sydafrikanske eksempel. Her går en fortidsfortælling, der udpeger gerningsmænd og ofre på begge sider og giver plads til forskellige ambivalente erindringer hånd $\mathrm{i}$ hånd 
med en entydig fordømmelse af apartheidsystemet. ${ }^{18}$ Historisering behøver altså ikke at udelukke en stillingstagen. Og identitet kan bygges på andet end endimensionale tolkninger, entydige domme og naturliggjorte værdier. Den kan være flertydig, skiftende og refleksiv.

Den historiepolitiske etik må med andre ord bidrage til en demokratisk historiekultur med rummelighed, tolkningspluralisme og flerperspektivitet. ${ }^{19}$ Det kan gøres ved både at anerkende gråzonerne, eller den organiske forbindelse mellem historie og erindring, mellem historie og politik, og

Karl Larsens bog hedder Dragon Niels Kjeldsen og hans Drabsmand. En undersogelse. Kristian Erslevs bekræftelse af Larsens resultater blev publiceret i Historisk Tidsskrift 7. rk., bd. 4, 1902-1904. Jf. i øvrigt Claus Bjørn: Dansk faghistorie mellem Apollo og Minerva. Signalement af et fag med kontinuitet. Kritik 127, 1997, s. 18-24 og Mads Findal Andreasen: En kamp mod vindmoller? - om faghistoriens formidlingsproblem. Eksemplificeret ud fra Karl Larsens og Aage Trommers udgivelser $i$ hhv. 1902 og 1971. Speciale ved Odense Universitet, 1998.

Nationaltidende 15. 4. 1902.

Claus Bryld og Anette Warring: Besattelsestiden som kollektiv erindring. Historie- og traditionsforvaltning af krig og besattelse 1945-1997. 1998.

Politiken 24. 8. 1998.

Se note 10 og 11.

Bryld og Waring 1998, s. 180-245 og 387415.

Ditlev Tamm i Ugeskrift for Retsvasen 1992, s. 183-91.

8 Aage Trommer: Hvad har vi naaet og hvad mangler vi? Knud J.V. Jespersen og Thomas Pedersen (red.): Besattelsen i perspektiv. 1995 samtidig ved at være bevidst om deres forskellige kendetegn og funktioner. $\mathrm{Og}$ det kan gøres ved på en og samme tid at indtage flere positioner i forhold til fortiden, hvilket åbner for en varsom differentiering mellem indlevelse, distance og stillingtagen og samtidig søger at bringe fortid og nutid i dialog. Kort sagt, ved at gå ind i sin tid, sådan som digteren Nordahl Grieg så smukt har sagt det. Dette vil formentlig føre til større indlevelse og dermed også til en sikrere vurdering af fortidens handlingsvalg og vores egen betingethed af disse valg - eller af manglen på samme.

Information 30. 10. 1971. Den erindringspolitiske konflikt i forbindelse med Trommers disputats er nærmere analyseret $\mathrm{i}$ Bryld og Warring 1998, s. 387-393 samt i Findal Andreasen 1998.

10 Nævnt i ledende artikel i History Workshop Journal issue 47, 1999, s. V.

11 Se f.eks. Pierre Nora: General Introduction: Between Memory and History. Realms of Memory: Rethinking the French Past. Vol. I: Conflicts and Divisions. 1996, s. 1-20. David Lowenthal: Possessed by the Past: The Heritage Crusade and the Spoils of History. 1996. Eric Hobsbawm: Identity History Is Not Enough. On History. 1997, s. 266-277, og samme: The new Threat to History. B.

Brivati et. al. (ed.): The contemporary History Handbook. 1996.

12 Raphael Samuel: Theatres of Memory. Vol. 1: Past and Present in Contemporary Culture. 1994. Bernard Eric Jensen: Historieformidling og erindringspolitik - i mindefesternes æra. Bernard Eric Jensen et. al. (ed.): Erindringens og glemslens politik. 1996, s. 235-258 og samme: Historiemedvetande. Begreppsanalys, samhällsteori, didaktik. Christer Karlegärd et al. (ed.): Historiedidaktik. 1997, s. 49-81. 
13 Jürgen Habermas: En slags sanering. De apologetiske tendenser i den tyske samtidshistorie, i Information 8. 5. 1987 og Historical Consciousness and Posttraditional Identity. Upubl. festtale 14. 5. 1987 ved modtagelsen af Sonningprisen.

14 Hans Kirchhoff: Den store myte om det danske folk i kamp. Om besættelsen i dansk kollektiverindring. Henrik Dethlefsen et. al. (red.): Fra mellemkrigstid til efterkrigstid. 1998, s. 395-421.

15 Se analyse af besættelsesjubilæerne og af Folketingets debatter om besættelsestiden i Bryld og Warring 1998, s. 138-179 og 245253.
16 Denne karakteristik er inspireret af Roland Barthes myteteori. Roland Barthes: Mytologier. 1996 (opr. 1957).

17 Dette diskuteres på interessant vis i relation til norsk historiedidaktik i Ivo de Figueiredo: Historie og moral. Okkupasjonsundervisningen i skolen. Egil Børre Johnsen (ed.): Forbildets forbilder. Norsk Sakprosa. 1996.

18 Helle Bjerg og Michael Valeur: ... kun på baggrund af sandheden. Opgor med fortiden $i$ Chile, Tjekkoslovakiet og Sydafrika. Speciale ved RUC, 1999.

19 Claus Bryld: Historikerens rolle i samfundet. Tove Kruse (ed.): Bud på historien. 1998, s. $110-139$. 